\title{
Władysław Szymański
}

\section{Polska wobec wyzwań}

\section{rozwojowych}

Jeżeli mówimy o wyzwaniach rozwojowych Polski, to w istocie mówimy o zagrożeniach, których chcielibyśmy uniknąć. Wyzwania są poważne, gdyż zagrożenia są groźne. Zagrożeniem może być niskie tempo wzrostu, gdyż grozi to zepchnięciem naszego kraju $z$ centrum społeczno-gospodarczego rozwoju Europy na jej peryferia. Jesteśmy bowiem krajem odstającym od średniego poziomu UE, co grozi odpływem młodych i zdolnych ludzi do krajów istotnie bogatszych. W konsekwencji może pogarszać się bilans podaży pracy i zwiększyć trudności związane $\mathrm{z}$ finansowaniem starzejącego się społeczeństwa.

Wyzwaniem rozwojowym jest nie tyle krótkookresowa dynamika, ale utrzymanie jej na poziomie przynajmniej o 2 punkty procentowe wyższym niż w Europie Zachodniej przez okres 15-20 lat, a więc utrzymanie wzrostu $\mathrm{w}$ oparciu o trwałe i silne podstawy. Trwałe podstawy wzrostu muszą być napędzane przez inwestycje i produktywność. Pozorny i przejściowy może być tylko wzrost budowany w oparciu o wzrost konsumpcji i dług. Najogólniej rzecz ujmując, dynamika wzrostu zależy od sumy tempa wzrostu zatrudnienia i tempa wzrostu wydajności pracy. Jeżeli bariery demograficzne uniemożliwiają wzrost tempa zatrudnienia, to wzrost można realizować $\mathrm{w}$ istocie jedynie przez wzrost wydajności pracy, a to wymaga odpowiednio duże- go wzrostu inwestycji i ich efektywności. Między pracą, kapitałem i efektywnością mogą bowiem być dokonywane pewnego rodzaju substytucje w zakresie kreowania wzrostu. Zła sytuacja demograficzna, cofnięcie reformy wydłużającej wiek pracy i niedostateczne otwieranie się na imigrację, to wymóg dodatkowego wzrostu nakładów inwestycyjnych, jeżeli chcemy osiągnąć odpowiednio wysoki wzrost gospodarczy. Wzrost nakładów inwestycyjnych wymaga odpowiednio wysokiej stopy oszczędności krajowych. W Polsce mamy nieznaczny stopień oszczędzania gospodarstw domowych i duży stopień ujemnych oszczędności związanych $\mathrm{z}$ deficytem finansów publicznych, w konsekwencji - czy się to komuś podoba czy nie - możliwość wysokiego wzrostu uzależniona jest w poważnym stopniu od napływu kapitału zewnętrznego. Napływ tego kapitału staje się tym ważniejszy im bardziej ograniczone zostaną fundusze unijne po 2020 tym roku. To z kolei wymaga stworzenia sprzyjających warunków politycznych i ekonomicznych, gdyż dla kapitału zewnętrznego ważna jest przewidywalność, która z kolei zależy od sytuacji finansowej kraju i poczucia stabilności.

W moim przekonaniu, warunkiem długotrwałego wzrostu (w granicach 4-4,5 proc. PKB) są inwestycje na poziomie ok. 25-30 proc. PKB. Tymczasem w 2016 r. udział ten wynosił około 18,5 proc. gdyż inwestycje istotnie spadły w stosunku do 2015 r. Udział 25 proc. PKB oznacza poziom inwestowania większy o ok. $100 \mathrm{mld}$ 
zł niż obecnie. Ograniczenie wymogu w zakresie poważnego wzrostu udziału inwestycji w PKB mogłyby nastąpić jedynie przy ograniczeniu niedoboru czynnika pracy i istotnego wzrostu efektywności w wyniku innowacyjności produktowej, technologicznej i organizacyjnej, co mogłoby doprowadzić do zmniejszenia kapitałochłonności przyrostowej.

Ostatnio w Polsce cieszymy się spadkiem bezrobocia do nienotowanego od wielu lat poziomu. Sygnalizuje on jednak - łącznie ze stopniowym otwieraniem się krajów UE na przypływ Ukraińców i większym odpływem ludzi na emerytury w wyniku cofnięcia reformy - narastanie problemów z niedoborem czynników pracy. Oczekiwać można zatem presji na wzrost płac, co może wywołać wzrost inflacji. W marcu 2017 inflacja wzrosła do 2,5 proc. Wzrostowi inflacji należy przeciwdziałać na wczesnym etapie poprzez uruchomienie narzędzi polityki fiskalnej i monetarnej. Skutkiem podniesienia stóp procentowych będzie zmniejszenie opłacalności podejmowanych inwestycji. Z drugiej strony, unikanie takich działań grozi podtrzymywaniem zjawiska inflacji, a w konsekwencji nawet załamanie złotego. Wyższy poziom inflacji w kraju niż w innych gospodarkach musi doprowadzić do takiej deprecjacji złotego.

$\mathrm{Z}$ kolei osłabienie złotego to wzrost kosztów obsługi długu. Zgadzam się z Jerzym Osiatyńskim [2017], że wychodzić z długu zaczniemy wtedy, gdy tempo wzrostu PKB będzie wyższe niż oprocentowanie papierów skarbowych. Dług przestaje rosnąć wtedy, gdy dochody państwa pokrywają bieżące wydatki wraz z oprocentowaniem długu. Im wyższe oprocentowanie tym trudniej zahamować wzrost długu. Nie zgadzam się jedynie z tym, że chodzi o uzyskanie wyższego wzrostu nie PKB, a PNB od stóp procentowych obligacji skarbowych. PKB jest miarą efektywności gospodarki $\mathrm{w}$ postaci produkcji dóbr i usług finalnych, wyrażających efekt czynników wytwórczych zlokalizowanych na terytorium danego kraju. PNB to taka sama miara, ale dotyczy efektów osiąganych przez obywateli danego kraju, niezależnie gdzie powstają. W Polsce PKB jest wyższy o kilka punktów procentowych od PNB. Jeżeli tempo wzrostu PKB jest niższe od 3 procent to PNB nie rośnie [Szymański, 2015].

Załamanie się finansów może nie tylko prowadzić do wzrostu oprocentowania papierów skarbowych finansujących obsługę długu, ale doprowadzić do kryzysu kursowego i głębokiego kryzysu gospodarczego.

\section{Wyzwania demograficzne}

Wcześniej stwierdziłem, że gospodarka Polski wymaga szybkiego odrobienia dystansu do średniej UE, co z kolei wymaga wzrostu gospodarczego przynajmniej o 2 proc. wyższego niż w krajach Europy Zachodniej przez 15-20 lat. Wynika to stąd, że wielkim zagrożeniem jest możliwość nakładania się spadku podaży siły roboczej z powodów demograficznych, na odpływ młodych i zdolnych do krajów UE, istotnie bogatszych. Prawie wszystkie kraje UE przeżywają kryzys demograficzny.

Pamiętać jednak należy, że czym innym jest starzenie demograficzne w kraju bogatym, a czym innym w kraju odstającym rozwojowo od czołówki europejskiej. Innym problemem jest starzenie w kraju takim jak Niemcy, a innym w kraju „na dorobku” jak Polska. Niemcy mają dwukrotnie wyższy PKB na mieszkańca, liczony według siły nabywczej i czterokrotnie wyższą płacę godzinową liczoną w euro. Kraj bogaty ma wysoką zdolność przyciągania ludzi młodych i zdolnych z zewnątrz. Tak więc kryzys demograficzny w Polsce jest dużo groźniejszy dlatego, że idzie w parze z kryzysem demograficznym wielu krajów Europy o wyższym poziomie rozwoju. $Z$ prognoz wynika, że liczba Polaków w kraju w 2050 roku zmniejszy się do $30 \mathrm{mln}$, a potencjał za- 
sobów pracy nawet do $9 \mathrm{mln}$ [Strzelecki, 2012]. Ministerstwo Rozwoju oceniło, że w 2050 roku w Polsce będzie o 5,3 $\mathrm{mln}$ mniej osób pracujących.

Nasz kraj stoi nie tylko i nie tyle przed kolejnymi niezbędnymi przedsięwzięciami służącymi wzrostowi dzietności, ale jednocześnie wymogami zatrzymania młodych i zdolnych w kraju. Aby nie dopuścić do nakładania się tych dwóch zjawisk w przyszłości, konieczne staje się jak najszybsze zmniejszanie różnic między Polską a średnim poziomem UE. Najbliższe 15-20 lat decydować będą o tym, czy Polska znajdzie się w centrum ekonomicznym Europy, bo przezwycięży kryzys demograficzny, czy znajdzie się na peryferiach, co dla starszego pokolenia będzie oznaczało degradację ekonomiczną i socjalną.

Polityka dążąca w sposób bezwzględny do szybkiego wyrównania poziomu rozwoju do średniej UE ma w dłuższym okresie znaczenie nie tylko dla zatrzymywania młodych i zdolnych w kraju, ale też dla przyciągania młodych i zdolnych $\mathrm{z}$ innych krajów. Tylko brakiem wyobraźni i zdolności przewidywania można tłumaczyć nieodpowiedzialne sprzyjanie przez polityków mentalności antyimigracyjnej. A przecież w przyszłości imigracja może być głównym ratunkiem kraju przed zepchnięciem na peryferie. Poziom i struktura imigracji będą w przyszłości zależne od miejsca Polski na mapie ekonomicznej Europy. Obecnie nie wykorzystujemy nawet najprostszej metody jaką jest repatriacja Polaków ze Wschodu.

Kryzys demograficzny bezwzględnie wymusza ekonomiczną samoobronę kraju, jaką jest szybkie odrobienie dystansu do średniej UE. Uczciwie można ją uznać za ekonomiczno-społeczną rację stanu.

Niestety, nie tylko nie ma powszechnej świadomości tych wyzwań, ale również świadomości w elitach politycznych. Najlepszym przykładem jest ponowne obniżenie wieku przechodzenia na emerytu- rę, w imię doraźnych celów politycznych. To bowiem nie tylko oznacza zwiększenie rocznego obciążenia ZUS o 10-20 mld zł i nie tylko dodatkowy spadek podaży pracy, ale w perspektywie większe obciążenie młodych utrzymaniem emerytów. A to będzie dodatkowy czynnik zwiększający „wypychanie” młodych do krajów istotnie bogatszych.

Obecnie, analizując nasze problemy demograficzne, skupiamy się na ludziach młodych, na ich niskim poczuciu bezpieczeństwa, na wielkim zakresie niepewności, co istotnie ogranicza dzietność. Program „500 plus” nieco poprawił sytuację. Pamiętać jednak należy, że w dłuższej perspektywie konsekwencje kryzysu demograficznego poniosą nie tyle młodzi wchodzący w wiek aktywności za 15-20 lat, ale ludzie którzy będą wchodzić w wiek poprodukcyjny, a więc obecni czterdziesto-, pięćdziesięciolatkowie. Młodym pozostanie wybór: pozostać czy szukać szczęścia gdzie indziej. Emeryci takiego wyboru mieć nie będą. Tak więc konsekwencje kryzysu demograficznego poniosą ludzie obecnie w średnim wieku, a więc ci, którzy dziś mają stery kraju w swoich rękach. Oni bowiem mogą nie tylko ponieść konsekwencje tego kryzysu, ale również mogą i powinni wpływać na decyzje intensyfikujące działania, które mogą neutralizować jego skutki.

\section{Wyzwania płynące ze strony finansów}

Zadania wzrostowe, o których była wcześniej mowa, w zasadniczym stopniu warunkowane będą sytuacją finansową kraju. W warunkach globalizacji rola finansów krajowych gwałtownie wzrasta, co jest zrozumiałe, jeżeli pamiętamy, że swobodnie przepływający kapitał jest szczególnie wrażliwy na sytuację finansową poszczególnych rynków i krajów, a potencjał spekulacyjny jest bardzo duży. Zasadniczym wyznacznikiem zmian społeczno-gospodarczych współczesności jest 
wyraźny wzrost niestabilności, niepewności, a niestabilność najbardziej i najdobitniej wyraża się w zagrożeniach $\mathrm{w}$ sferze finansowej.

Patrząc na zagrożenia płynące ze sfery finansów, z punktu widzenia poszczególnych krajów można powiedzieć, że ich sytuacja będzie w zasadniczym stopniu zależna od tego, czy kapitał będzie chciał do nich przypływać i pozostawać, czy odwrotnie będzie chciał od nich odpływać. Istotne jest, że odpływać może również kapitał krajowy.

Wielu ekonomistów obawia się obecnie wzrostu odpływu kapitału krajowego w wyniku zbyt rygorystycznych ostatnio rozwiązań walki z unikaniem płacenia podatków. Przykładem może tu być wprowadzana zasada, że jeżeli sprawa trafia do sądu, to majątek będący przedmiotem sporu jest zamrożony. Jerzy Hausner pisze: Jeszcze nigdy duze zorganizowane banki inwestycyjne - np. szwajcarskie, nie miaty tylu polskich klientów, którzy chca powierzyć swoje aktywa, czyli wycofuja je z polskiego obiegu gospodarczego [Hausner, 2016].

Długookresowe zagrożenia wynikają z braku warunków zachęcających do inwestycji, co w konsekwencji ogranicza zdolności finansowania inwestycji. Zagrożenia w krótkim czasie wynikają natomiast z groźnych skutków nagłej ucieczki kapitału. Takie ruchy w najgorszej sytuacji prowadzą do kryzysu kursowego i gospodarczego. Pamiętać należy, że często kapitał napływa wtedy, gdy jest najmniej potrzebny, a odpływa wtedy, gdy potrzeba go najbardziej.

Współcześnie powyższych zagrożeń nie można odrywać od ogólnej sytuacji występującej na światowym rynku kapitałowym i finansowym. Chimeryczność, drapieżność i spekulacyjny charakter rynków finansowych zwiększają znaczenie stabilnych finansów krajowych. O jakościowej zmianie finansów światowych świadczy m.in. zadłużenie łączne gospodarstw domowych, przedsiębiorstw i rządów, które wzrosło z niewiele ponad 100 proc. PKB w skali świata do 350 obecnie [Orłowski, 2016]. A wartość instrumentów pochodnych wzrosła między 1990 a 2014 r. ze 100 proc. światowego PKB do 1000 proc., czyli dziesięciokrotności światowego PKB. Niestabilność światowych finansów wynika również z tzw. poluzowania pieniężnego, z wpompowania dodatkowego pieniądza do gospodarki światowej dla podtrzymywania koniunktury. Kraje posiadające pieniądz światowy, wpompowywały w ostatnich latach dodatkowo ponad 2 biliony dolarów rocznie. W dużej części ten pieniądz nie wykreował realnego popytu, tylko powiększył pule pieniądza krążącego w obiegu.

Sytuacja finansowa Polski jest trudna i złożona nie tyle ze względu na poziom długu publicznego $\mathrm{w}$ stosunku do PKB, który wynosi 52-54 proc., a który został w 2014 roku zmniejszony o $150 \mathrm{mld}$ zł poprzez wykorzystanie środków z OFE. Trudna sytuacja finansów krajowych wynika przede wszystkim z występowania słabości na wielu polach, które w niesprzyjających warunkach mogą połączyć się w groźny ogólny skutek. Wielość niekorzystnych zjawisk o różnym charakterze sprawia, że nie tyle groźne są poszczególne słabości, ale ich suma i możliwość kumulacji w trudnych gospodarczo sytuacjach.

Mamy strukturalny deficyt finansów publicznych w postaci blisko 3 proc. PKB. Tak wysoki deficyt przy wysokim wzroście PKB bliskim 4 proc. świadczy o strukturalnym charakterze, gdyż grozi skokowym jego wzrostem przy załamaniu dynamiki PKB. Ogranicza to możliwość wykorzystania polityki fiskalnej w sytuacji załamania koniunktury i grozi ponownym wejściem Polski w unijną procedurę nadmiernego zadłużenia $\mathrm{z}$ całym zestawem restrykcji. Procedura likwidacji nadmiernego deficytu obowiązywała przez sześć lat, była ona pochodną wzro- 
stu deficytu w okresie walki ze skutkami kryzysu w latach 2008-2010 i została zakończona w maju 2015. W latach 2010 2014 ograniczono wydatki o 3,8 punktów procentowych PKB. Taka skala obniżenia wydatków była możliwa m.in. dzięki obowiązującej od 2011 roku wydatkowej regule dyscyplinującej, ograniczającej tempo wzrostu wydatków sztywnych do 1 proc. realnie w skali roku [Raport Ministerstwo Gospodarki, 2015]. Obecna presja na wydatki grozi tym, że efekty w dyscyplinowaniu finansów mogą zostać zaprzepaszczone.

Charakter naszego zadłużenia, według podziału stosowanego przez wybitnego znawcę kryzysu finansowego Hymana Minsky'ego, to nie zadłużenie zabezpieczone, ani nie zadłużenie spekulacyjne, a zadłużenie o charakterze piramidy finansowej. Oznacza ono, że bieżące dochody po pokryciu bieżących wydatków (nie zawsze) nie pokrywają oprocentowania długu i spłaty rat. W konsekwencji wymuszają sprzedaż obligacji nie tylko pokrywających oprocentowanie, ale rolowanie długu, czyli zaciąganie kredytów na spłatę rat kredytowych. Problem staje się złożony, gdy duży jest udział kredytów krótkoterminowych i duży udział kapitału zagranicznego w finansowaniu obsługi długu. A taka jest sytuacja Polski.

Pamiętać należy, że rynki finansowe mogą dziś rzucić większość krajów na kolana, zwłaszcza wtedy, gdy zaczynają one na większą skalę spekulować instrumentami pochodnymi $\mathrm{w}$ postaci polis ubezpieczeniowych, tzw. CDS, które służą do przenoszenia ryzyka. Poprzez najczęściej sztuczne podnoszenie CDS, co ma oznaczać wzrost ryzyka obligacji danego kraju, wpływają na wzrost ich oprocentowania. Przy wysokim poziomie obligacji finansujących obsługę długu danego kraju, łatwo można doprowadzić do szybkiego wzrostu długu i niewypłacalności.

Szczególnym problemem Polski w sferze finansów jest jeden $z$ najwyższych na świecie deficytów międzynarodowej pozycji inwestycyjnej, który pokazuje, jaka część majątku krajowego jest finansowana netto przez obcy kapitał. Im większy deficyt tym więcej kapitału mobilnego w postaci obcych zysków i dywidend. I tylko dobra wola i interes obcych właścicieli decydują, czy te dywidendy będą w kraju inwestowane czy też odpłyną za granicę, zwiększa się wtedy również potencjalny zakres kapitału, który przy niesprzyjających warunkach będzie chciał z kraju odpłynąć. Duży udział kapitału zagranicznego w finansowaniu majątku krajowego, to jednocześnie wymóg odróżniania w analizach ekonomicznych przedsiębiorstw w kraju od przedsiębiorstw polskich.

Ważnym dla oceny finansów kraju jest szerokie wykorzystanie cen transakcyjnych przez transnarodowe korporacje funkcjonujące $\mathrm{w}$ Polsce, a więc wykorzystywanie cen pomiędzy przedsiębiorstwami powiązanymi dla unikania opodatkowania, poprzez ucieczki do rajów podatkowych. Po aferze w 2014 roku, w której udowodniono, że Luksemburg ściągnął do siebie 340 największych holdingów, Komisja Europejska obliczyła, że poprzez wykorzystywanie cen transakcyjnych kraje UE straciły 300 mld euro na niepłaconych podatkach od zysku, w tym Polska ok. 46 mld euro [Gajewski, 2017].

Wszystkie powyższe uwagi o finansach Polski świadczą o wielkim uzależnieniu naszej gospodarki od kapitału zagranicznego i jego ruchów. Pamiętać jednocześnie należy, że dotychczas poważnym, nieformalnym, ale realnym ubezpieczeniem naszej sytuacji finansowej, są pokaźne fundusze europejskie, których napływ nie tylko istotnie poprawia zasoby finansowe, ale wzmacnia bilans finansowy kraju, ważny dla oceny przez rynki finansowe jego stabilności i poziomu ryzyka.

Duże prawdopodobieństwo, że po 2020 roku poziom funduszy europejskich będzie istotnie niższy, powinno być 
traktowane jako poważne wyzwanie dla finansów. Spadną bowiem nie tylko darmowe, zewnętrzne środki finansowe, ale ograniczony zostanie istotny filar stabilności finansowej kraju.

Kumulacja wielu trudnych zjawisk ze sfery finansów, w obliczu istotnego spadku za trzy lata funduszy unijnych, wymaga działań uprzedzających. A więc wymaga odpowiedniego przygotowania środków neutralizujących obiektywne pogorszenie sytuacji po 2020, zwłaszcza, że przed Polską stają poważne zadania inwestycyjne, niezbędne dla gospodarki odrabiającej dystans do średniego poziomu UE.

Zadania inwestycyjne są duże a oszczędności krajowe małe, uwzględniając deficyt finansów publicznych jako oszczędności ujemne, czyli dezoszczędności. Oszczędności krajowe oscylują w granicach 15-16 proc. PKB. A bezwzględny wymóg odrabiania dystansu rozwojowego do średniej unijnej to wymóg przynajmniej 25 proc. inwestycji w PKB. Bez takiego poziomu inwestycji i oparcie się tylko na oszczędnościach krajowych przekreśliłoby wysoki poziom wzrostu i zagroził peryferyzacją kraju, jako skutku nałożenia się niskiej i już przesądzonej w najbliższym 20-leciu podaży zasobów pracy $\mathrm{z}$ przyczyn demograficznych, na szybki odpływ młodych i zdolnych do krajów istotnie bogatszych. W tej sytuacji będziemy przez długi jeszcze okres skazani na inwestycje zagraniczne, a więc na przypływ kapitału. Bez stabilności finansowej i przewidywalności politycznej to nie będzie możliwe.

Największym jednak zagrożeniem jest możliwy nagły, gwałtowny odpływ kapitału spowodowany jakąś złą sytuacją wewnętrzną lub zewnętrzną. Przy dużym udziale kapitału mobilnego w postaci dywidend od kapitału zagranicznego ok. 90 mld zł i wielkości kapitału portfelowego 601 mld zł, nagły odpływ kapitału grozi efektem domina i poważnym kryzysem kursowym i gospodarczym.

\section{Europa i euro}

\section{jako wyzwanie dla Polski}

Z dotychczasowych rozważań wynika, że dla bezwzględnego wymogu jakim jest wysoka i trwała dynamika, by odrobić dystans do średniego poziomu UE poważną barierą są finanse i wielkim wyzwaniem staje się przygotowanie gospodarki na swoisty wstrząs, jakim może być istotne ograniczenie funduszy europejskich po 2020 roku. Jeszcze większym wyzwaniem jest wymóg zmiany sposobu myślenia o integracji europejskiej, a przede wszystkim, jak wielką rolę może spełniać integracja wraz z przyjęciem euro dla złagodzenia zagrożeń, jakie płyną ze strony finansów.

W ocenie integracji wielu uważa, że są granice integracji i należy ją sprowadzić do unii celnej. Popełniają oni błąd ahistoryczności, chcą mianowicie w XXI wieku, w okresie procesów wywołanych globalizacją, działać w zakresie integracji tak, jak wskazywały na to warunki z połowy XX w. Można powiedzieć, że dotychczasowy proces globalizacji doprowadził do zasadniczego spadku suwerenności państwa $\mathrm{w}$ stosunku do rynków kapitałowych i finansowych. Państwo straciło to, co je cechowało dawniej, że miało „moc i politykę”, współcześnie moc odeszła do rynków kapitałowych, co rzutuje bezpośrednio na jakość i skuteczność polityki.

W tej sytuacji, jednym z najważniejszych działań jest podejmowanie przedsięwzięć, które chociaż w części odbudowywać będą tę straconą moc w stosunku do rynków kapitałowych. Integracja należy do najważniejszych przedsięwzięć temu służącym. Unia Europejska, a zwłaszcza unia walutowa, jest w stosunku do rynków kapitałowych siłą nieporównanie większą od siły poszczególnych państw. Prawdziwa walka kraju o suwerenność, to współcześnie walka o suwerenność w stosunku do siły rynków kapitałowych i finansowych. Przedstawione wcześniej zagrożenia płynące ze strony finansów dla 
Polski i jej perspektywy, w sytuacji odrzucenia euro i godzenia się na zepchnięcie na peryferie UE, zostałyby zdecydowanie spotęgowane.

W moim przekonaniu, skutecznym lekarstwem na powyższe zagrożenia byłby akces i energiczne przygotowanie do wejścia do strefy euro. Jednocześnie, wejście do strefy euro byłoby skutecznym neutralizatorem szoku, jaki jest możliwy w sferze finansowej i gospodarczej po istotnym spadku funduszy europejskich po 2020 roku. Wejście do strefy euro spowodowałoby następujące pozytywne konsekwencje ekonomiczne:

- likwidacji ulegałaby groźba kryzysu kursowego, która w Polsce jest nie tylko możliwa, ale ze względu na duży udział kapitału zewnętrznego w finansowaniu gospodarki miałaby głęboko kryzysowe konsekwencje,

- istotnie zwiększyłby się stopień bezpieczeństwa dla kapitału krajowego i zagranicznego, co przy stojących przed Polską zadaniach wzrostowych i inwestycyjnych ma bardzo duże znaczenie,

- obniżone zostałyby w sposób znaczący koszty transakcyjne i obniżone koszty kredytów i obligacji,

- do dyspozycji kraju pozostałyby nadzwyczajne środki ekstra, w postaci 105 mld euro rezerw (450 mld zł), które po wejściu do strefy euro byłyby zbędne i mogłyby służyć tak potrzebnemu wsparciu zadań w zakresie odrabiania dystansu.

Powyższe korzyści wejścia do euro są w Polsce zdecydowanie większe od kosztów, przede wszystkim ze względu na założone zadania i wielkość zagrożeń stojących przed krajem. Koszty to rezygnacja $\mathrm{z}$ własnych środków w postaci pieniądza i kursu waluty, dla wspomagania się podatkiem inflacyjnym i konkurencyjnością cenową. Każdy dobry ekonomista wie, że tak można się wspierać tylko na krótką metę.
Często podnoszony argument o złych doświadczeniach krajów południa Europy, tzw. PIGS, nie jest trafiony, gdyż wini się euro, a nie błędną politykę gospodarczą tych krajów. Zapomniały one, że taniego kredytu i łatwego dostępu do kapitału nie można wykorzystywać do wyższego wzrostu dochodów niż pozwala na to wzrost wydajności. Wtedy bowiem spada konkurencyjność, a nie można się wspomagać obniżaniem kursu własnej waluty, bo już jej nie ma. Kto zmierza do euro, na takie błędy nie może sobie pozwolić.

Wyżej przedstawione argumenty, to argumenty ekonomiczne za wejściem do strefy euro, argumenty polityczne są nie mniej ważne, gdyż wynikają z geopolitycznej racji stanu. Ich ranga rośnie, gdyż coraz więcej jest sygnałów świadczących o tym, że prawdziwa UE będzie tworzona przez tych, którzy do strefy euro wejdą. W Polsce coraz bardziej martwi język antyeuropejski i wiele działań władzy, które sprawiają, że Polska naszym partnerom unijnym wydaje się nieobliczalna i odrzucająca wartości, na bazie których została zbudowana UE.

Upadek UE byłby dla Polski o wiele groźniejszy niż dla innych krajów, gdyż jesteśmy na dorobku i nam bardziej niż innym potrzebny jest parasol ochronny wobec agresywności rynków kapitałowych i solidarnościowa pomoc finansowa. Zarazem znajdujemy się na wschodnich rubieżach Unii, które są najbardziej narażone na geopolityczne wstrząsy. Jest duże prawdopodobieństwo, że upadek strefy euro byłby w konsekwencji równoznaczny z upadkiem UE jako takiej. W tej sytuacji, akces Polski do wejścia do strefy euro należy również traktować jako działanie służące ochronie samej Unii przed rozpadem. Po zwycięstwie Emmanuela Macrona we Francji kreuje się okaleczony przez wypadnięcie Polski układ weimarski. Macron postawił na Niemcy, a Niemcy czekające długo na zmianę stanowiska 
Polski, zostały zmuszone postawić na Francję bez Polski. Pamiętać należy, że ze względu na zakres współpracy gospodarczej i wagę stabilności w Europie Środkowej, Niemcy traktowały wspólną politykę z Polską jako potrzebne wzmocnienie w oddziaływaniu na całą UE. Rodzi się na naszych oczach scenariusz głębszej integracji strefy euro, powstania budżetu strefy i paktu wojskowego. Wszystko wskazuje, że Polska na własne życzenie będzie poza tą strefą, a więc w jakimś stopniu realizowany scenariusz będzie przeciw nam. Rezygnując z akcesu do strefy euro skazujemy się więc na peryferyzację w UE, a to może zdecydować o skazaniu nas na peryferie społeczno-gospodarcze. Ahistoryczne myślenie o suwerenności i brak rozumienia wagi suwerenności wobec siły rynków kapitałowych i finansowych mogą pogrzebać nasze długofalowe aspiracje rozwojowe.

\section{Wyzwania konkurencyjne}

Nawet skuteczne pokonywanie barier finansowych i europejskich nie wystarczy, by móc liczyć na długookresowy wysoki wzrost. Trzeba do tego dodać zdolności konkurencyjne gospodarki.

Współcześnie, w wyniku globalizacji i otwarcia rynków, gospodarka stopniowo przekształcała się z gospodarki o charakterze popytowym, a więc gospodarki ograniczonej przez wielkość popytu, w gospodarkę podażową ograniczoną przez potencjał konkurencyjny, a więc jakość i koszty podaży. Konkurencyjność warunkuje bowiem nie tylko zdolność do korzystania $\mathrm{z}$ popytu rynku globalnego, ale i zdolność do sprostania w kraju współzawodnictwu o popyt rynku wewnętrznego $\mathrm{z}$ przedsiębiorstwami z zewnątrz. Warto pamiętać, że w Polsce na rynku wewnętrznym towary importowane to ponad 50 proc. W sytuacji, gdy charakter gospodarki kraju przekształca się z popytowego na podażowy, powinna zmieniać się istota i kształt interwencjo- nizmu gospodarczego państwa. Z popytowego - bo z popytu rynku krajowego korzystają nie tylko podmioty krajowe - na interwencjonizm podażowy. Taki interwencjonizm sprzyja podniesieniu jakości krajowych zasobów produkcyjnych (edukacja, zaplecze badawczo-rozwojowe) oraz przedsięwzięć służących podniesieniu innowacyjności i konkurencyjności przedsiębiorstw. Dawniej państwo mogło chronić przedsiębiorstwa przed konkurencją zewnętrzną poprzez różne formy protekcjonizmu i jednocześnie wspomagać je przez sterowanie popytem. Obecnie przedsiębiorstwa muszą wykazywać zdolność sprostania coraz bardziej otwartej i zwiększającej natężenie konkurencji firm rynku globalnego, również na rynku wewnętrznym.

Polska stoi obecnie wobec zmian wewnętrznych i zewnętrznych warunków, które przyczyniają się do wygasania dotychczasowych podstaw konkurencji, w których dominowały przede wszystkim relatywnie niskie koszty płac. W sytuacji trudnych zadań, związanych $\mathrm{z}$ odrobieniem dystansu rozwojowego, nie można dopuścić by państwo było bierne i liczyło jedynie na oddolną aktywność przedsiębiorstw. Konieczna jest bowiem również innowacyjna polityka państwa, wspierająca konkurencyjność, a przede wszystkim jej jakościowe zmiany.

Pamiętać musimy, że świat rozwiniętego kapitalizmu wszedł $\mathrm{w}$ proces stagnacji $\mathrm{z}$ ciągłymi zagrożeniami zjawisk kryzysowych [Palley, 2012]. A przecież czym innym jest odrobienie dystansu, gdy mamy do czynienia z dobrą koniunkturą i szybkim wzrostem popytu, jak miato to miejsce w poprzednich okresach, a czym innym odrobienie dystansu, gdy popyt w Europie nie będzie szybko rósł, a nasz eksport w 80 proc. kierowany jest do krajów Europy. Co innego oznacza być konkurencyjnym przy szybkim wzroście ogólnego popytu, a co innego gdy popyt 
nie rośnie, a nasi przedsiębiorcy muszą go zdobyć, wypychając z istniejącego już popytu innych. Bez odpowiedniej jakości konkurencji będzie to niemożliwe. Dominacja dotychczas konkurencji niejakościowej, a więc oparcia jej na niskich cenach i niskich kosztach płacowych, musi przekształcić się w odczuwalnym stopniu na konkurencję jakościową zależną od marki produktu i zaufania klientów.

Płytka konkurencyjność oparta na niskich płacach daje w sprzyjających warunkach efekty na krótką metę, bo przyciąga kapitał obcy, który przypływa z postępem technicznym i kulturą biznesową. Taka konkurencyjność w dłuższym okresie powoduje, że napływający kapitał utrwala presję na utrzymanie niskich płac i poddostawczego charakteru polskich podmiotów gospodarczych. Jest to szczególnie niekorzystne w dłuższej perspektywie dla rozwoju kapitału ludzkiego, a zwłaszcza kapitału intelektualnego. Kapitał zewnętrzny, tworząc presję na utrzymanie niskich płac i rozwój poddostawczej funkcji, stwarza warunki dla działalności rutynowej, a nie działalności twórczej.

Niskie płace to z jednej strony brak twórczego zaangażowania przedsiębiorców, a z drugiej pracowników. Przedsiębiorcy nie muszą podejmować ryzykownych działań innowacyjnych, poszukiwać nowych trudnych rozwiązań, gdyż niskie płace gwarantują, że zwykłe administrowanie wystarczy, a więc odsuwa się przymus twórczej przedsiębiorczości. Z drugiej strony, pracownicy przy niskich płacach i dominacji rutynowego działania, tracą bodziec do zawodowego zaangażowania i doskonalenia. Zabija się bowiem aspiracje niezbędne do rozwoju kapitału ludzkiego. Dotychczasowy model, oparty na płytkiej kosztowej konkurencyjności, doprowadził do dużej asymetrii między szybkim dążeniem młodego pokolenia do kształcenia i zdobywania kwalifikacji, a niskim poziomem i zakresem rozwoju dziedzin, które oferują miejsca pracy wymagające wysokich kwalifikacji. To staje się istotnym czynnikiem wypychania młodych zdolnych do krajów bogatych. Nie potrafiono stworzyć warunków do wykorzystania najcenniejszego potencjału, jakim jest wykształcona młodzież.

Z danych Eurostatu wynika, że liczona w euro płaca godzinowa w Polsce jest trzykrotnie niższa od średniej płacy godzinowej w UE, ale na Ukrainie jest prawie trzykrotnie niższa niż w Polsce. Montażownie produktów wymyślonych przez innych można obecnie łatwo przenieść w miejsca bardziej sprzyjające niż Polska.

Oparcie konkurencyjności na niskich płacach w dłuższym okresie czyni gospodarkę mniej stabilną, bo zwiększa się czynniki ulegające zmianom niezależnie od tego co dzieje się w kraju, a zmniejsza się czynniki stabilizujące, czyli konsumpcję krajową. Ograniczenie wzrostu dochodów wpływa ujemnie na wzrost oszczędności krajowych. W ten sposób kreuje się niedobór własnego kapitału i potrzebą jego zastąpienia kapitałem zagranicznym. Kapitał zagraniczny wymusza zaś niskie płace, niskie oszczędności i potrzebę oparcia się w nadmiernym stopniu na jego zasobach i zasadach. Narzuca to jednocześnie poddostawczy i podwykonawczy charakter gospodarki.

Według Eurostatu, w Polsce jest kilkanaście punktów procentowych mniejszy udział płac w PKB niż w krajach Europy Zachodniej. Jednocześnie nastąpił największy spadek tego udziału, poza $\mathrm{Ru}$ munią. Spadek ten w stosunku do $2000 \mathrm{r}$. wyniósł ok. 9,5 punktu procentowego do 46 proc. PKB w 2014 r.

Ważna jest świadomość, że nie można w sposób prymitywny odchodzić od konkurencji opartej na niskich płacach, bez stworzenia warunków i sfer konkurencji jakościowej. Krytyka modelu konkurencji opartej na niskich płacach nie może w żadnym przypadku uruchomić presji do ich podnoszenia. Wtedy, nie mając podstaw konkurencji jakościowej, likwidacji 
uległaby również konkurencyjność kosztowa $\mathrm{z}$ katastrofalnymi konsekwencjami dla gospodarki. Pamiętać bowiem należy, że nie wylewa się brudnej wody, gdy nie ma szans na czystą.

W analizie konkurencyjności i charakteru działalności, należy oddzielić przedsiębiorstwa działające w Polsce od przedsiębiorstw polskich. Przedsiębiorstwa zagraniczne w Polsce i przedsiębiorstwa z dominującym udziałem kapitału zewnętrznego, mają zdecydowanie większy zakres firm zlecających i wykorzystujących polskich podwykonawców. Polskich podwykonawców wykorzystują jednocześnie przedsiębiorstwa z innych krajów. Konsekwencją są wszelkie słabości, jakie wynikają ze zlecanej działalności poddostawczej. We współczesnym, globalnym rynku nie tylko jest duża przewaga ekonomiczna zleceniodawców, która dodatkowo szybko wzrasta. Poddostawcy są poddostawcami łatwo zastępowalnymi, w konsekwencji uległymi sile zleceniodawców. Dla przykładu, w Polsce wytwarza się samochody, jednak wymyślanie ich konstrukcji oraz dystrybucja i marketing znajdują się w rękach kapitału zagranicznego. Idea, pomysł i projektowanie oraz sfera marketingowa i sprzedaż to najwyżej opłacalne fazy. W Polskich rękach znajdują się, bazujące na zagranicznych projektach, wytwarzanie elementów i montaż. Te fazy cechuje nie tylko niski zwrot $\mathrm{z}$ poniesionych nakładów, ale także poddostawczy charakter, łatwo zastępowalny, co obniża siłę przetargową w stosunku do zleceniodawcy.

Jak zmienić charakter polskich przedsiębiorstw, by przekształcić je z biernych zleceniobiorców w silnych zleceniodawców, należy do najważniejszych, a zarazem najtrudniejszych pytań i zadań gospodarczych.

Zleceniodawców można podzielić na dwie grupy. Pierwsza, to najsilniejsze przedsiębiorstwa, które podstawę zleceń budują na przewadze technologicznej i dużej zdolności tworzenia szeroko rozumianych prototypów. Takie firmy podstawę bogacenia się widzą w innowacjach i związanych z tym dużych nakładach na proces badawczy (R\&D). Druga grupa to ci, którzy stawiają na wykorzystanie arbitrażu gospodarczego, czyli zróżnicowania rynku, a więc stawiają na większą od konkurentów wiedzę o rynku.

We współczesnym świecie innowacje wymagają dużych nakładów na badania i rozwój, gdyż im większe nakłady tym większe szanse powodzenia. W miarę wzrostu nakładów na badania, spada ryzyko $\mathrm{w}$ poszukiwaniu innowacji produktowych i technologicznych. Polskie firmy są małe i stać je na mniej w konkurencji tworzenia prototypów. Muszą one w większym stopniu szukać możliwości w związkach z nauką. Państwo może tworzyć różne bodźce do rozwijania współpracy nauki z praktyką. Należy działać zdecydowanie w kierunku rozwoju innowacji, ale efekty w tym zakresie prawdopodobnie nie będą ujawniać się szybko i na miarę potrzeb rozwojowych. W tej sytuacji należy liczyć na większe i szybsze efekty w wykorzystaniu arbitrażu gospodarczego rynku globalnego.

\section{Wymóg wykorzystania rynku globalnego}

Polska stoi przed zadaniem długookresowego wysokiego wzrostu, bez wysokich oszczędności i przy występowaniu dużych barier finansowych. Kraj stoi więc z jednej strony wobec wymogu jakościowych zmian w konkurencyjności, z drugiej zaś wymogu zmian kapitałooszczędnych. Uważam, że te trudne zadania można najłatwiej zrealizować, gdy państwo i przedsiębiorstwa skoncentrują swą działalność na zdobyciu przewagi w poznaniu i wykorzystaniu rynku globalnego. Każdy ekonomista wie, że warunkiem wykorzystania rynku jest wcześniej zdobyta o nim wiedza. Ten, kto zdobywa taką przewagę, w konsekwencji zdobywa 
przewagę w jego wykorzystaniu. Obecnie największe szanse daje przewaga wiedzy o rynku globalnym.

Otwierając rynek globalny, proces globalizacji ujawnia olbrzymie różnice $\mathrm{w}$ kosztach, płacach, cenach, kursach, podatkach, a więc ujawnia szanse dla tych, którzy potrafią to wykorzystać, czyli szanse konkurencyjne skupiają się wtedy na arbitrażu gospodarczym.

W ostatnich dziesięcioleciach wykorzystanie arbitrażu gospodarczego było najłatwiejszą i najszerzej wykorzystywaną drogą do szybkiego bogacenia się korporacji transnarodowych. Był to jednocześnie skuteczny sposób zdobywania przewag konkurencyjnych.

Inne szanse wynikające z procesu globalizacji dotyczą wykorzystania różnic rozwojowych między krajami w zakresie postępu technicznego i kultury biznesowej. Kraje będące na wyższym poziomie rozwoju i ich przedsiębiorstwa, mogą przenosić rozwiązania techniczne, instytucjonalne i organizacyjne, które u nich nie są już innowacjami, do krajów o niższym poziomie rozwoju i sprzedawać je jako rzeczywiste innowacje.

Globalizacja przyspieszyła zmianę realizacji kosztów transakcyjnych w formule R.H Coase’a. Coraz większa jest świadomość, że koszty tej samej działalności w przedsiębiorstwie są wyższe od kosztów zleceń na zewnątrz (koszty transakcyjne). Analiza konsekwencji zmian relacji kosztów transakcyjnych, stała się $\mathrm{w}$ praktyce zasadniczym sposobem poprawy pozycji konkurencyjnej. Nie może to dziwić, gdyż taka analiza ukazuje korzyści, jakie można uzyskać z wykorzystania poddostawców i podwykonawców rynku globalnego.

Aby stać się zleceniodawcą i wykorzystywać ogrom poddostawców rynku globalnego, niekoniecznie trzeba wielkich nakładów kapitałowych. Można bowiem do uzyskania przewagi informacyjnej o rynku globalnym wykorzystać istniejący w kraju kapitał intelektualny, by stawać się koordynatorem sieci poddostawców.

Zmienność i niestabilność współczesnego rynku wymuszają wzrost elastyczności przedsiębiorstw. Sposobem na elastyczność jest rozkooperowanie produkcji, a więc wykorzystanie poddostawców i podwykonawców. Firmy zmuszone są do szukania sposobów ograniczania kosztów stałych. Aby wykorzystać warunki rynku globalnego, a zarazem przerzucić koszty stałe na innych, najlepiej z punktu widzenia biznesu wykorzystywać poddostawców i podwykonawców rozmieszczonych na rynku globalnym, czyli stawiać na outsorcing kontraktowy. Wtedy wykorzystujemy środki produkcji i kapitał poddostawców. Firma może być wówczas elastyczna, bo nie jest obciążona kosztami stałymi i kosztami niszczenia starego, nie jest blokowana przez stare decyzje i stare inwestycje. Wykorzystując majątek produkcyjny poddostawców i podwykonawców, firmy wiodące przerzucają na nich koszty technicznych i strukturalnych zmian wynikających $\mathrm{z}$ wprowadzenia nowych rozwiązań. Ważne jest przede wszystkim to, że firma wiodąca nie buduje strategii pod presją świadomości, że musi wykorzystać własne środki produkcji, ale zaczyna od tego, czego oczekują klienci rynku globalnego. A to wręcz skok w umiejętności dostosowania się do wymogów rynku, a zarazem wzrost elastyczności, która jest niczym innym, jak umiejętnością dostosowywania się do zmian rynkowych.

Wykorzystywanie olbrzymiej masy poddostawców rynku globalnego, to wykorzystywanie faktu, że koszty zleceń są niższe niż koszty samej działalności w przedsiębiorstwie. Stąd tworzenie sieci niezależnych własnościowo podmiotów z inicjatorem i koordynatorem setek, a nawet tysięcy niezależnych własnościowo poddostawców, z którymi koordynator wchodzi w umowne porozumienie. Przywództwo opiera się na wspólnym interesie, partnerstwie i świadomej współpracy. 
Przykładem takiej sieci jest firma Li\&Fung z Hongkongu, która nie jest właścicielem żadnej fabryki. W 2006 roku była koordynatorem pracy sieci 8300 dostawców, obsługiwanych przez ponad 70 biur rozlokowanych w ponad 40 krajach. Firma pośrednio dawała zatrudnienie ponad $2 \mathrm{mln}$ osób w sieci dostawców, ale sama nie zatrudniała żadnego pracownika produkcyjnego. Zaopatrywała rynek $\mathrm{w}$ artykuły konsumpcyjne na sumę $8 \mathrm{mld}$ dolarów. Rentowność jej aktywów przekroczyła 38 proc. [Fung, Wind, 2008].

Od kilku lat postuluję postawienie $w$ Polsce na tworzenie inteligentnych firm poprzez organizowanie specjalnych inkubatorów dla ich powstawania [Szymański, 2011]. To firmy typu wcześniej wspomnianej Li\&Fung, które rozwijając proces rozkooperowania, zbliżają się do modeli pustej firmy. Taka firma w ścisłym znaczeniu niczego nie produkuje, gdyż w całości polega na zewnętrznych źródłach dostaw półfabrykatów, montażu i usług. Funkcjonuje przy minimalnej organizacji wewnętrznej, opierając się na doskonałej infrastrukturze informatycznej i wykwalifikowanej kadrze badającej rynek globalny i zarządzającej siecią kontaktów.

Takie firmy powstają spontanicznie, jako inicjatywa niektórych przedsiębior- ców światowych. Propozycje tworzenia inkubatorów byłyby formą innowacji publicznej, dającej efekty na dużą skalę. Wsparcie państwa powinno zaistnieć $\mathrm{w}$ trzech sferach. Pierwsza sfera to wsparcie infrastruktury informatycznej i instytucjonalnej, która warunkuje zdobywanie przewagi tych firm w zdobywaniu wiedzy o rynku globalnym, wymagałoby to ilościowego i jakościowego przekształcenia komórek informacyjno-gospodarczych w placówkach dyplomatycznych. Druga sfera to zainicjowanie tworzenia inkubatorów takich firm. Wyselekcjonowanie zdolnych młodych ludzi, zaszczepienie w nich idei i wiedzy o rynku globalnym oraz szansach inteligentnych firm. Trzecia sfera wsparcia, ważna we wstępnej fazie rozwoju inteligentnych firm, to stworzenie przez państwo i banki państwowe odpowiedniego systemu gwarancji i ubezpieczeń. Początek takiej firmy jest trudny, bo jest ona nieznana, nie potrafiła jeszcze przez historię swego działania sama wykreować podstawy zaufania do siebie.

Globalizacja spowodowała, że pierwszy raz na taką skalę można zdobywać rynek światowy bez dużego kapitału, bez krajowego popytu, bez kompetencji produkcyjnych. Drogą do tego jest wiedza o rynku globalnym i outsorcing kontraktowy.

\section{Bibliografia:}

1. Fung V.K., Wind Y. [2008], Konkurowanie w ptaskim świecie, Warszawa, Wydawnictwo Akademii Leona Koźmińskiego.

2. Gajewski G. [2018], rozmowa G. Sroczyńskiego, „Gazeta Wyborcza”, nr 15/04.

3. Hausner J. [2016], rozmowa C. Michalskiego, „Newsweek”, nr 04/04.

4. Orłowski W.M. [2016], Trzecia faza rozwoju, „Polityka”, nr 4.

5. Osiatyński J. [2017], rozmowa J. Solskiej, „Polityka”, nr 25.

6. Palley T.I. [2012], From Financial Crisis to Stagnation, Cambridge University.

7. Plan [2016], Plan na rzecz odpowiedzialnego rozwoju, Ministerstwo Rozwoju, Warszawa.

8. Strzelecki Z. [2012], Gtówne zagrożenia dla Polski, koreferat dla Komitetu Prognoza Polski Plus, Warszawa.

9. Szymański W. [2011], Niepewność i niestabilność gospodarcza, Warszawa, Difin.

10. Szymański W. [2015], Świat i Polska wobec wyzwań, Warszawa, Difin.

Prof. zw. dr hab. Władysław Szymański, Społeczna Akademia Nauk. 